\title{
BIODIVERSITY OF THE CHEMICAL CONSTITUENTS IN THE EPIPHYTIC LICHENIZED ASCOMYCETE RAMALINA LACERA GROWN ON DIFFERENCE SUBSTRATES CRATAEGUS SINAICUS, PINUS HALEPENSIS, AND QUERCUS CALLIPRINOS
}

\author{
Lumir Ondrej Hanus ${ }^{\mathrm{a} *}$, Marina Temina ${ }^{\mathrm{b}}$, Valery Dembitsky ${ }^{\mathrm{a}}$ \\ a Department of Medicinal Chemistry and Natural Products, School of Pharmacy, P.O. Box 12065, Hebrew University, \\ Jerusalem 91120, Israel \\ ${ }^{b}$ Biodiversity and Biotechnology Center of Cryptogamic Plants and Fungi, Institute of Evolution, University of Haifa, Haifa \\ 31905, Israel \\ e-mail:lumir@cc.huji.ac.il
}

Received: June 15, 2008; Accepted: July 8, 2008

Key words: Ramalina lacera/Lichen/Fatty acids/Lipids/Betaine lipids/Glycolipids/Aromatic compounds/Crataegus sinaicus/Pinus halepensis/Quercus calliprinos

Aim: The identification and evaluation of lichen metabolite production by the epiphytic lichenized ascomycete Ramalina lacera collected from different substrates: Crataegus sinaicus, Pinus halepensis, and Quercus calliprinos.

Methods: Chemical constituents were characterized by GC-MS, HPLC, HR-TLC, and other chemical methods.

Results: The most abundant fatty acids were $\alpha$-linolenic acid, oleic acid, and palmitic acid but a considerable variability of the ester composition from one to another was found. A comparison of neutral lipids, glycolipids, polar lipids and fatty acid composition of the tree-growing lichen Ramalina lacera was done. Diacylglyceryl-N,N,N-trimethylhomoserine, diaclyglycerylhydroxymethyl-N,N,N-trimethyl- $\beta$-alanine, phosphatidylcholine, and phosphatidylinositol were found as major components among polar lipids. Diffractaic, lecanoric, norstictic, protocetric, and usnic acids were isolated as major aromatic compounds in all samples of $R$. lacera.

Conclusions: We evaluated a diversity of fatty acids, lipids, and aromatic compounds produced by the samples of Ramalina lacera growing on different tree-substrates, Crataegus sinaicus, Pinus halepensis and Quercus calliprinos.

\section{INTRODUCTION}

Lichens are symbiotic associations between certain types of fungi (usually ascomycetes) and various green algae or cyanobacteria ${ }^{1,2}$. Lichens have been used for a number of years as natural bioindicators for various heavy metals and as sources of information for environmental monitoring ${ }^{3,4}$. These organisms have both algal and fungal properties and produce $n$-alkanes ${ }^{5}$, unusual betaine ether glycerols ${ }^{6}$, glyco- and phospholipids ${ }^{7,8}$, and saturated, unsaturated, branched ${ }^{8,9}$, and halogenated fatty acids ${ }^{10}$. Many different bioactive secondary metabolites have also been isolated from lichen species ${ }^{11-13}$ which have been used in pharmaceutical and biotechnological sciences and industry $^{14-16}$.

Some Ramalina species are usually used as food in some Central and South Eastern Asian countries. Thus, lichens are used as traditional food by Rai and Limbu communities of East Nepal. Lichens Ramalina farinacea, $R$. conduplicans, $R$. sinensis, and $R$. subfarinacea are cooked mixed with various foods ${ }^{17}$. Ramalina farinacea and $R$. conduplicans are usually used as traditional food by Rai and Limbu communities of East Nepal. Lichens are cooked mixed with various foods ${ }^{17}$. Since the beginning of the 20th century hair powder of Ramalina calicaris, and Ramalina spp. Have been used in cosmetics in Europe $^{18}$, and India ${ }^{19}$ respectively. Extracts from the lichen
Ramalina farinacea were evaluated against fifteen clinical isolates of Staphylococcus aureus ${ }^{20}$. The aqueous extract of the Ramalina farinacea has folkloric reputation for the treatment of mental disorders in Africa; and tinctures have also been used for treatment of ringworm tinea in Nigeria ${ }^{21}$. In southwestern province Yunnan (China), the Yi, Dai, and Han ethnic peoples cook these two species of Ramalina (R. conduplicans and R.sinensis) to prepare a traditional cold dish served at marriage banquets ${ }^{22}$.

The lichen substances are unique as they are unknown in other plant sources. Lichens contain many characteristic aromatic compounds with known antiviral, antimicrobial, antiproliferative, antimitotic, antioxidant activities ${ }^{23}$. Lichens may be a good potential source of bioactive phytochemicals ${ }^{7,13,24}$.

In this study, we evaluated which fatty acids, lipids, and aromatic compounds are produced by the samples of Ramalina lacera growing on different tree-substrates, Crataegus sinaicus, Pinus halepensis and Quercus calliprinos.

\section{MATERIALS AND METHODS}

Plant material

Ramalina lacera (With.) J.R. Laundon (family Ramalinaceae) is a fruticose lichen growing on Crataegus si- 
Table 1. Fatty acid composition of the Ramalina lacera growing on different substrates

\begin{tabular}{|c|c|c|c|}
\hline \multirow[b]{2}{*}{ Fatty acids } & \multicolumn{3}{|c|}{ S u b s t r a t e $s$} \\
\hline & $\begin{array}{c}\text { Crataegus sinaicus } \\
\text { (sample 1) }\end{array}$ & $\begin{array}{c}\text { Pinus halepensis } \\
\text { (sample 2) }\end{array}$ & $\begin{array}{c}\text { Quercus calliprinos } \\
\text { (sample 3) }\end{array}$ \\
\hline Saturated & 26.00 & 29.38 & 18.36 \\
\hline $12: 0$ & 1.26 & 0.98 & 0.56 \\
\hline $13: 0$ & 0.54 & 0.67 & 0.51 \\
\hline 14:0 & 1.87 & 1.96 & 2.14 \\
\hline $15: 0$ & 0.54 & 0.62 & 0.71 \\
\hline iso-15:0 & 0.81 & 0.72 & 0.63 \\
\hline anteiso-15:0 & 0.62 & 0.63 & 0.51 \\
\hline $16: 0$ & 12.94 & 11.88 & 8.47 \\
\hline iso-17:0 & 0.53 & 0.54 & $>0.5$ \\
\hline anteiso-17:0 & 0.62 & $>0.5$ & $>0.5$ \\
\hline $18: 0$ & 5.13 & 4.96 & 3.29 \\
\hline $20: 0$ & 1.14 & 0.97 & 0.56 \\
\hline Monoenes & 17.63 & 15.39 & 17.73 \\
\hline $15: 1(n-8)$ & 0.88 & 0.72 & 0.76 \\
\hline $16: 1(n-9)$ & 5.14 & 2.15 & 4.96 \\
\hline $16: 1(n-7)$ & 1.73 & 2.22 & 1.86 \\
\hline $18: 1(n-11)$ & 0.67 & 0.74 & 0.56 \\
\hline $18: 1(n-9)$ & 6.98 & 7.23 & 8.14 \\
\hline $18: 1(n-7)$ & 1.58 & 1.60 & 0.94 \\
\hline $20: 1(n-9)$ & 0.65 & 0.73 & 0.51 \\
\hline Dienes & 7.21 & 7.39 & 9.62 \\
\hline $16: 2(n-4)$ & 0.72 & 0.62 & 0.55 \\
\hline $18: 2(n-6)$ & 5.94 & 6.16 & 8.57 \\
\hline $20: 2(n-6)$ & 0.55 & 0.61 & 0.50 \\
\hline Polyenes & 49.16 & 47.84 & 54.28 \\
\hline $16: 3(n-6)$ & 1.76 & 2.22 & 2.77 \\
\hline $16: 3(n-3)$ & 2.98 & 2.87 & 3.11 \\
\hline $18: 3(n-6)$ & 2.14 & 2.67 & 3.04 \\
\hline $18: 3(n-3)$ & 35.87 & 30.19 & 29.70 \\
\hline $16: 4(n-3)$ & 3.14 & 2.98 & 3.49 \\
\hline $18: 4(n-3)$ & 1.85 & 1.70 & 2.98 \\
\hline $20: 4(n-6)$ & 0.96 & 1.21 & 2.25 \\
\hline $20: 4(n-3)$ & 1.34 & 2.11 & 3.66 \\
\hline $20: 5(n-3)$ & 1.12 & 1.89 & 3.28 \\
\hline
\end{tabular}

naicus (family Rosaceae, voucher specimen HAI-0-30521 (MT), Pinus halepensis (family Pinaceae, voucher specimen HAI-0-30522 (MT), and Quercus calliprinos (family Fagaceae, voucher specimen HAI-0-30523 (MT), in the forests on Mount Carmel at 800 meters above sea level. All samples were collected in July 2003 from Mount Carmel, Sekher Pool (North Israel), identified and voucher specimen HAI-0-30521-305023 (MT) are deposited in the lichen herbarium of Biodiversity and Biotechnology Center of Cryptogamic Plants and Fungi (Haifa).

\section{General extraction procedures}

Clearly fresh lichen (50-75 g of each sample) was extracted (Soxhlet) with ethanol-water-HCl (90:10:1, $\mathrm{v} / \mathrm{v} ; 60{ }^{\circ} \mathrm{C}$ ) over $72 \mathrm{~h}$ (fraction 1 ). The ethanolic residue was further extracted by light petroleum (60-80 ${ }^{\circ} \mathrm{C}$, fraction 2), and then dichloromethane (fraction 3 ).
Fraction 1 was concentrated in vacuum at $35^{\circ} \mathrm{C}$, water layer was lyophilized, and then dissolved in $2 \mathrm{ml}$ of ethanol. Fraction 2 and 3 were separately concentrated to dryness in vacuum at $5{ }^{\circ} \mathrm{C}$ under reduced pressure, and then dissolved in $2 \mathrm{ml}$ of a cold mixture ethanol-dichloromethane $(1: 1, v / v)$, which was used for separation by HPLC, TLC, and followed chemical analysis.

Gas chromatographic-mass spectrometric analysis

A Hewlett Packard 6890 (series II) gas chromatograph modified for glass-capillary work and a HP-GC mass selective detector (5973B MSD) were used. Fatty acid methyl esters were prepared and analyzed by GC fitted with serially coupled capillary columns: the RTX 1 column ( $30 \mathrm{~m}$, ID $0.32 \mathrm{~mm}$, film thick-ness $0.25 \mu \mathrm{m}$; Restek, USA) was coupled with a second capillary column (RTX 1701, $30 \mathrm{~m}$, $0.32 \mathrm{~mm}, 0.25 \mu \mathrm{m}$ film; Restek, USA). The instrumental 
Biodiversity of the chemical constituents in the epiphytic lichenized ascomycete Ramalina lacera grown on difference substrates Crataegus sinaicus, Pinus halepensis, and Quercus calliprinos

Table 2. Lipid composition of the Ramalina lacera growing on different substrates

\begin{tabular}{|c|c|c|c|}
\hline \multirow[b]{2}{*}{ Lipid classes } & \multicolumn{3}{|c|}{ S ub s t rates } \\
\hline & $\begin{array}{c}\text { Crataegus sinaicus } \\
\text { (sample 1) }\end{array}$ & $\begin{array}{l}\text { Pinus halepensis } \\
\text { (sample 2) }\end{array}$ & $\begin{array}{c}\text { Quercus calliprinos } \\
\text { (sample 3) }\end{array}$ \\
\hline Total lipids (mg/g dry wt) & 36.9 & 42.4 & 51.3 \\
\hline Neutral lipids (mg/g dry wt) & 22.1 & 26.8 & 32.1 \\
\hline Free fatty acids ${ }^{\#}$ & $2.6 \pm 0.2$ & $1.6 \pm 0.1$ & $2.9 \pm 0.4$ \\
\hline Free sterols & $3.9 \pm 0.4$ & $6.6 \pm 0.3$ & $4.6 \pm 0.2$ \\
\hline Diacylglycerols & $1.5 \pm 0.1$ & $2.3 \pm 0.2$ & $3.1 \pm 0.3$ \\
\hline Triacylglycerols & $10.1 \pm 0.6$ & $8.5 \pm 0.7$ & $12.3 \pm 0.9$ \\
\hline Steryl esters & $2.9 \pm 0.2$ & $4.2 \pm 0.2$ & $6.2 \pm 0.5$ \\
\hline Wax esters & $1.6 \pm 0.1$ & $3.2 \pm 0.3$ & $3.0 \pm 0.6$ \\
\hline Glycolipids (mg/g dry wt) & 9.0 & 8.0 & 11.3 \\
\hline MGDG & $3.2 \pm 0.6$ & $2.6 \pm 0.4$ & $3.2 \pm 0.3$ \\
\hline DGDG & $5.0 \pm 0.8$ & $4.7 \pm 0.6$ & $7.2 \pm 0.5$ \\
\hline SQDG & $0.8 \pm 0.2$ & $0.7 \pm 0.1$ & $0.9 \pm 0.1$ \\
\hline Polar lipids (\% of total polar lipids) & 5.8 & 7.6 & 7.9 \\
\hline DGTA & $14.2 \pm 0.8$ & $12.6 \pm 0.9$ & $8.9 \pm 0.6$ \\
\hline DGTS & $18.6 \pm 0.9$ & $21.3 \pm 1.3$ & $25.2 \pm 1.9$ \\
\hline PC & $35.6 \pm 1.4$ & $44.2 \pm 3.7$ & $34.9 \pm 2.8$ \\
\hline $\mathrm{PE}$ & $6.8 \pm 0.4$ & $7.4 \pm 0.6$ & $14.3 \pm 0.9$ \\
\hline PI & $15.3 \pm 0.7$ & $11.2 \pm 0.8$ & $16.7 \pm 0.7$ \\
\hline PA & $2.2 \pm 0.2$ & $0.9 \pm 0.1$ & \\
\hline $\mathrm{X}$ & $7.3 \pm 0.4$ & $2.4 \pm 0.2$ & \\
\hline
\end{tabular}

${ }^{\#}$ Mean \pm standard deviation.

Abbreviations: MGDG, monogalactosyl diacylglycerol; DGDG, digalactosyl diacylglycerol;

SQDG, sulfoquinovosyl diacylglycerol, DGTA, diacylglyceryltrimethylalanine;

DGTS, diacylglyceryltrimethylhomoserine; PC, phosphatidylcholine; PE, phosphatidylethanolamine;

PI, phosphatidylinositol; phosphatidic acid; X, non-identified polar lipid

Table 3. Identified aromatic compounds of the Ramalina lacera growing on different substrates

\begin{tabular}{|l|c|c|c|}
\hline \multirow{2}{*}{$\begin{array}{l}\text { Aromatic } \\
\text { Compounds }\end{array}$} & \multicolumn{3}{|c|}{ S u b s t r a t e s } \\
\cline { 2 - 4 } & $\begin{array}{c}\text { Crataegus sinaicus } \\
\text { (sample 1) }\end{array}$ & $\begin{array}{c}\text { Pinus halepensis } \\
\text { (sample 2) }\end{array}$ & $\begin{array}{c}\text { Quercus calliprinos } \\
\text { (sample 3) }\end{array}$ \\
\hline Orsellinic acid & 11.4 & 12.5 & 19.2 \\
\hline Lecanoric acid & 22.5 & 26.2 & 21.7 \\
\hline Protocetric acid & 27.4 & 32.8 & 41.2 \\
\hline Diffractaic acid & 28.7 & 33.7 & 38.9 \\
\hline Homosekikaic acid & 4.9 & 5.9 & 29.4 \\
\hline Usnic acid & 26.8 & 25.3 & 22.8 \\
\hline Norstictic acid & 23.5 & 29.9 & $\mathbf{1 7 9 . 4}$ \\
\hline Total & $\mathbf{1 4 5 . 2}$ & $\mathbf{1 6 6 . 3}$ & \\
\hline
\end{tabular}

settings used were as follows: initial temperature, $40^{\circ} \mathrm{C}$; initial time, $2.00 \mathrm{~min}$; rate, $2^{\circ} \mathrm{C} / \mathrm{min}$; final temperature, $300{ }^{\circ} \mathrm{C}$, final time, $20 \mathrm{~min}$; injection port, $180{ }^{\circ} \mathrm{C}$; carrier gas, He: flow rate, $25.0 \mathrm{~mL} / \mathrm{min}$. The MS detector operated at $194{ }^{\circ} \mathrm{C}$; ionization energy, $70 \mathrm{eV}$. The scan range, 30 to $700 \mathrm{~m} / z$ at 0.9 scan per sec. Solvent delay, $9 \mathrm{~min}$. Fatty acid methyl esters were identified using mass spectral libraries search (Wiley $7^{\text {th }}$, and NIST-98).
High-Performance Liquid Chromatographic Analysis

The dried samples from fractions were reconstituted in $200 \mu \mathrm{L}$ of methanol and analyzed using a Hewlett Packard 1100 HPLC system (Hewlett-Packard 1100 HPLC System w/ UV/VIS detector, includes: G1311A Quaternary Pump, G1314A UV/Vis Detector, G1313A Autosampler, G1322A Vacuum Degasser, Solvent Module, HP Chemstation with Computer System) with a photo diode array detec- 
tor set at a range of $200-450 \mathrm{~nm}$; all peaks were analyzed at $254 \mathrm{~nm}$. An analytical reverse phase $\mathrm{C}_{18}$ column (A Spherisorb 5 ODS 2 column $250 \times 4.6 \mathrm{~mm}, 5 \mu \mathrm{m}$; (Kontron) was used as the stationary phase. Mobile phase A contained $10 \%$ methanol and $90 \%$ water brought to a pH of 2.0 with phosphoric acid, and mobile phase B was $100 \%$ methanol. A linear gradient was applied over $30 \mathrm{~min}$ starting with $100 \%$ of mobile phase A at the start to $100 \%$ mobile phase B at the end. Chromatograms were analyzed by Hewlett Packard software; retention time and absorbance spectra were used to identify compounds, and also pure compounds were used for spectral analysis. Orsellinic and usnic acids were obtained from Sigma-IL, and used also as standard compounds. Isolated metabolites were identified with ${ }^{13} \mathrm{C}-\mathrm{NMR}$, IR, UV, and chemical methods as described previously ${ }^{11}$.

\section{High-Performance Thin-Layer Chromatographic Analysis}

Total lipids were separated by column chromatography to neutral, glycolipid, and polar lipid fractions on silica gel (Merck 63/200 mesh). The obtained fractions were further analyzed by HR-TLC as described previously ${ }^{25,26}$. Neutral lipids were separated on $10 \times 20 \mathrm{~cm}$ silica gel plates (Silica Gel 60, Merck) with toluene-hexane-formic acid (150:70:2, v/v) mixture. Glycolipids were separated using acetone-benzene-water (100:40:9, v/v) mixture as described $^{27,28}$. Polar lipids, including betaine lipids and phospholipids, were separated with the help of chloroform-acetone-methanol-formic acid-water (150:20:10:10:4, $\mathrm{v} / \mathrm{v}$ ) mixture in the first direction, and acetone-benzene-formic acid-water (200:30:4:10, v/v) one in the second direction as described previously ${ }^{29}$.

\section{RESULT AND DISCUSSION}

Ramalina lacera is a moderately xeric epiphytic fruticose lichen that grows in the Mediterranean areas on different shrubs and trees. These epiphytic species belonging to the family Ramalinaceae were chosen for a comparative examination of their fatty acid, polar lipids, and aromatic compounds. The GC-MS analysis of fatty acids in R. lacera, which grows on Crataegus sinaicus, Pinus halepensis, and Quercus calliprinos, revealed a high polyenoic content in species which grows on the Palestine oak $Q$. calliprinos ( $54.28 \%$, Table 1 ), but much lower amounts of such acids in two other ones, viz. $49.16 \%$ and $47.84 \%$, respectively. The amounts of trienoic acids, however, were higher in the samples from tree-growing species, $42.75 \%$ (sample 1), $37.95 \%$ (sample 2) and $38.62 \%$ (sample 3 ). A total of 11 saturated fatty acids were identified, with $n-16: 0$ and $n-18: 0$ as major ones (8.47-12.94 \% and 3.29-5.13\%, respectively). Total saturation in various species varied from 18.36 (sample 3 ) to $26 \%$ (sample 1). All three species studied had almost identical monoenoic and dienoic acid contents. Among other interesting acids, 16:4(n-3), the presence of which is characteristic for green marine $\operatorname{algae}^{27}$, and 18:4(n-3), characteristic for brown marine $\operatorname{algae}^{28}$, were detected. It seems likely that the lichen photobiont synthesize these acids ${ }^{5}$. In sample 3 , the total level of isomers of 20:4(n-6) and 20:4(n-3) was considerably higher than that from the rest of the examined species, reaching $5.91 \%$. These amounts of arachidonic acid isomers are the highest known in the lichen literature with regard to the total lipid extract, although still higher levels have been found in individual lipid classes, for example, Peltigera aphthosa ${ }^{8}$.

Total lipid content was studied in all collected lichen species, having common climatic peculiarities. Table 2 shows total lipid compositions in lichens collected during July; total lipid content in such lichens show variations from 36.9-51.3 mg/g dry wt. Neutral lipids make up the highest percentage among of total lipids (Table 2) and vary from 22.1-32.1 mg/g dry wt. Examination of neutral lipids using HR-TLC revealed the domination of TAG and diacylglycerols over the rest of neutral lipids thereby representing more than $50 \%$ in the majority of lichen species. Free fatty acids, free sterols and its esters were also detected. The amount of glycolipid is comparatively lower than that of neutral lipids and varies between 8-11\%.

Examination of the lichen polar lipids, including betaine lipids (DGTA and DGTS) and phospholipids showed phosphatidylcholine (PC) to be the major phospholipids with concentrations varying from 34.9 to $44.2 \%$ of total polar lipids (Table 2). The PC content in various fungal species is known to vary from 20 to $55 \%$, whereas PC contained in red algal species varies from 61.6 to $77.8 \%$ (ref. ${ }^{23}$ ). Phosphatidylethanolamine (PE) was detected in all lichen species studied; its level was low in the first two species (ca $6.8 \%$ ), but reached $14.3 \%$ in sample 3. Phospatidylinositol was also found in all species studied; its level was highest in sample 3 (16.7 \%). Both betaine lipids were detected in all samples; their level varies from 8.9 to $14.2 \%$ for DGTA, and 18.6-25.2 \% for DGTS.

DGTS, one of the three known betaine lipids, has been the object of many studies ${ }^{24}$. Betaine lipids occur in bacteria $^{30}$, fungi ${ }^{31,32}$, moss species ${ }^{33}$, and in a number of brown, green and red algae 26, 29,34 as well as in lichens $^{7,35,36}$. As for higher plants, betaine lipids have been found in bryophytes $^{31,37}$, in ferns ${ }^{38}$, and other plants ${ }^{39}$. DGTA was detected in fungi ${ }^{24}$, marine brown algae ${ }^{27}$, and microalgal species $^{34}$.

HPLC has become more widely used as an effective analytical tool for the separation and identification of lichen substances ${ }^{40}$. Feige and co-workers ${ }^{41}$ used HPLC with reversed-phase columns and gradient elution for separation of 331 lichen compounds. We used HPLC for separation aromatic compounds from three lichen samples. Seven aromaric acids were identified (Table 3). Total aromatic compounds varies from 145.2 (sample 1) to $179.4 \mu \mathrm{g} / 100 \mathrm{~g}$ dry wt (sample 3 ). Examination of the lichen aromatics showed lecanoric, protocetric, diffractaic, usnic, and norstictic acids to be the major metabolites (Table 3).

Earlier, aromatic compounds were isolated from the genus Ramalina. Thus, norstictic and salazinic acids 
were isolated from Ramalina subfarinacea ${ }^{42}$, and from Ramalina farinacea (Hawaii) ${ }^{43}$; usnic and sekikaic acids were isolated from Indian $R$. tayloriana growing on sandal trees $^{44}$; and orsellic, lecanoric, diffractaic, protocetraric, usnic and norstictic acids were isolated from $R$. lacera ${ }^{45}$. Usnic acid was detected in Ramalina yasudae ${ }^{46}$. Trivaric and divaric acids are the major products of the Ramalina americana, and lecanoric and gyrophoric acids were identified as minor metabolites ${ }^{47}$. Chilean native Ramalina species: R.chilensis, and $R$. farinacea contains lecanoric, divaricatic, salazinic, usnic, norstictic, and ramalinolic acids $^{48,49}$. New Zealand's Ramalina species contains: $R$. arabum - norstictic and salazinic acids; $R$. geniculata - salazinic and sekikaic acids; $R$. glaucescens - homosekikaic, lecanoric, and sekikaic acids; $R$. inflaca and $R$. unilateralis - divaricatic acid; $R$. pacifica - protocetraric acid; and $R$.peruviana - homosekikaic, ramalinolic, and sekikaic acids ${ }^{50}$. Diffractaic, orsellinic, and usnic acids were isolated from $R$. subcomplanata (Nepal) ${ }^{51}$.

All samples of $R$. lacera produced the same aromatic acids but in different amounts. Some biological activities of isolated aromatic compounds from $R$.lacera have also been reported. Thus, we recently reported that orsellic, lecanoric, diffractaic, protocetraric, usnic and norstictic acids from $R$. lacera possess antibacterial and antifungal activities $^{45}$. Diffractaic acid exhibited antifungal activity against the phytopathogenic fungus Cladosporium sphaerospermum $^{52}$. Potent antiproliferative agents, usnic and diffractaic acids showed inhibitory activities against the human keratinocyte cell line $\mathrm{HaCaT}$, with $\mathrm{IC}_{50}$ values of 2.1 and $2.6 \mu \mathrm{M}$, respectively ${ }^{53}$. Diffractaic acid also showed strong inhibitory activity against tumor promoter-induced Epstein-Barr virus ${ }^{54}$. Orsellic acid revealed antibacterial activity against Escherichia coli, Ralstonia solanacearum, Staphylococcus aureus, and Xanthomonas campestris vesicatoria ${ }^{55}$. Protocetraric acid showed activity against yeasts Candida albicans and C. glabrata $^{56}$, and norstictic acid was active against Aeromonas hydrophila, Bacillus subtilis, Listeria monocytogenes, Proteus vulgaris, Staphylococcus aureus, Streptococcus faecalis, Candida albicans, and C. glabrata ${ }^{56}$. (+)-Usnic acid and (-)-usnic acid isolated from the lichen Ramalina farinacea showed cytotoxic and genotoxic activities against V-79 (Chinese hamster lung fibroblast-like) and A549 (human lung carcinoma epithelial-like) cell lines ${ }^{57}$. Usnic acid exhibited antiviral, antiprotozoal, antiproliferative, anti-inflammatory and analgesic activities as reported in recent review article $^{58}$.

Thus, the analyses of fatty acids, lipids and aromatic compounds from three samples of the $R$. lacera showed the presence of rare fatty acids: $16: 4(n-3)$ and 18:4(n-3). Such acids were found in some marine algal species ${ }^{59}$. As the photobiont component may form the main part of lichens, the presence of the above acids is to be expected for lichens. Hexadeca-4,7,10,13-tetraenoic acid 16:4(n-3), octadeca-6,9,12,15-tetraenoic acid (stearidonic acid), 18:4(n-3), and $\alpha$-linolenic acid were isolated from marine green alga Ulva fasciata (family Ulvaceae) ${ }^{60}$. These polyunsaturated fatty acids (PUFAs) showed potent algicidal activity against microscopic high toxic alga Heterosigma akashiwo $\left(\mathrm{LC}_{50} 1.35 \mu \mathrm{g} / \mathrm{mL}, 0.83 \mu \mathrm{g} / \mathrm{mL}\right.$, and $1.13 \mu \mathrm{g} / \mathrm{mL}$ for (16:4, 18:4, and $\alpha$-linolenic acid, respectively), and the result demonstrated the potential of these PUFAs for practical harmful algal bloom control. These polyunsaturated acids isolated from the diatom Navicula delognei $\mathrm{f}$. elliptica, showed significant antibacterial activity against Staphylococcus aureus, S.epidermidis, Salmonella typhimurium, and Proteus vulgaris ${ }^{61}$. $\alpha$-Linolenic acid [18:3(n-3)] and oleic acid [18:1(n-9)] were found as major unsaturated fatty acids. $\alpha$-Linolenic acid showed anti-inflammatory activity $^{62}$. Among polar lipids, both betaine ether lipids (DGTA and DGTS) as well as PC, and PI were found as major lipid components.

\section{REFERENCES}

1. Yuan XL, Xiao SH, Taylor TN. Lichen-like symbiosis 600 million years ago. Science 2005; 308:1017-1020.

2. Honegger R. The lichen symbiosis - what is so spectacular about it? Lichenologist 1998; 30:193-212.

3. Klos A, Rajfur M, Stodolka M, Waclawek M, Waclawek W. Chemometric methods in environmental monitoring using lichens. Ecol Chem Engineer 2006; 13:515-522.

4. Garty J. Biomonitoring atmospheric heavy metals with lichens: theory and application. Crit Rev Plant Sci 2001; 20:309-371.

5. Torres A, Dor I, Rottem E, Srebnik M, Dembitsky VM n-Alkane and fatty acid variations in the lichen Xanthoria parietina, their photobiont Trebouxia sp. and mycobiont, from Jerusalem hills. Eur J Biochem 2003; 270:2120-2125.

6. Dembitsky VM, Bychek IA, Rozentsvet OA. Diacylglyceryltrimethy lhomoserine and phospholipid composition of some lichen species. Phytochemistry 1993; 34:1535-1536.

7. Dembitsky VM. Lipids of Lichens. Prog Lipid Res 1992; 31:373-397.

8. Dembitsky VM, Rezanka T, Bychek IA. Fatty acid and phospholipids from lichens of the order Leconorales. Phytochemistry 1992; 31:851-853.

9. Dembitsky VM, Rezanka T, Bychek IA, Shustov MV. Identification of fatty acids from Cladonia lichens. Phytochemistry 1991; 30:4015-4018.

10. Rezanka T, Dembitsky V. Novel brominated lipidic compounds from lichens of Central Asia. Phytochemistry 1999; 51:963-968.

11. Torres A, Hochberg M, Pergament I, Smoum R, Niddam V, Dembitsky VM, Temina M, Dor I, Lev O, Srebnik M, Enk CD. A new UV-B absorbing mycosporine with photo protective activity from the lichenized ascomycete Collema cristatum. Eur J Biochem 2004; $271: 780-784$

12. Huneck S. The significance of lichens and their metabolites. Naturwissenschaften 1999; 86:559-570.

13. Hunek S, Yoshimura I. Identification of Lichen Substances. Springer-Verlag, Berlin, Heidelberg, 1996.

14. Zovko M, Kosalec I, Kalodjera Z, Partl A, Pepeljnjak S. Characteristics, chemistry and use of lichens. Farm Glasnik (Croatia) 2007; 63:227-243.

15. Oksanen I. Ecological and biotechnological aspects of lichens. Appl Microbiol Biotech 2006; 73:723-734.

16. Müller K. Pharmaceutically relevant metabolites from lichens. Appl Microbiol Biotech 2001; 56:9-16.

17. Bhattarai T, Subba D, Subba R. Nutritional value of some edible lichens of east Nepal. J Appl Bot-Angew Bot 1999; 73:11-18.

18. Smith AL. Lichens. Chapter X. Economical and technical. Cambridge Univ. Press, p. 419, 1921.

19. Richardson DHS. The Vanishing Lichens. Their History, Biology and Importance (section on human uses). Hafner Press (Macmillan Publishing Co.), New York, p. 118, 1974. 
20. Esimone CO, Adikwu MU. Susceptibility of some clinical isolates of Staphylococcus aureus to bioactive column fractions from the lichen Ramalina farinacea (L.) Ach. Phytotherapy research 2002; 16:494-496.

21. Esimone CO, Adikwu MU. Antimicrobial activity and cytotoxicity of Ramalina farinacea. Fitoterapia 1999; 70:428-431.

22. Wang LS, Narui T, Harada H, Culberson CF, Culberson WL. Ethnic uses of lichens in Yunnan, China. Bryologist 2001; 104:345-349.

23. Upreti DK, Chatterjee S. Significance of lichens and their secondary metabolites: a review. Fungi 2007; 2:169-188.

24. Dembitsky VM. Betaine ether-linked glycerolipids: chemistry and biology. Prog Lipid Res 1996; 35:1-51.

25. Dembitsky VM, Rezanka T, Bychek IA. Fatty acid composition of Parmelia lichens. Phytochemistry 1992; 31:841-843.

26. Dembitsky VM, Rezanka T, Rozentsvet OA. Lipid composition of three macrophytes from the Caspian Sea. Phytochemistry 1993; 33:1015-1019.

27. Dembitsky VM, Rozentsvet OA, Pechenkina EE. Glycolipids, phospholipids and fatty acids of some brown algae species from the Black Sea. Phytochemistry 1990; 29:3417-3421.

28. Dembitsky VM, Pechenkina-Shubina EE, Rozentsvet OA Glycolipids and fatty acids of some seaweeds and marine grasses from Black Sea. Phytochemistry 1991; 30:2279-2283.

29. Dembitsky VM, Rozentsvet OA. Diacylglyceryltrimethylhomos erines and phospholipids of some green marine macrophytes. Phytochemistry 1989; 28:3341-3343.

30. Riekhof WR, Andre C, Benning C. Two enzymes, BtaA and BtaB, are sufficient for betaine lipid biosynthesis in bacteria. Archiv Biochem Biophys 2005; 441:96-105.

31. Kunzler K, Eichenberger W. Betaine lipids and zwitterionic phospholipids in plants and fungi. Phytochemistry 1997; 46:883-892.

32. Istokovics A, Morita N, Izumi K, Hoshino T, Yumoto I, Sawada MT, Ishizaki K, Okuyama H. Neutral lipids, phospholipids, and a betaine lipid of the snow mold fungus Microdochium nivale. Can J Microbiol 1998; 44:1051-1059.

33. Dembitsky VM, Rezanka T. Distribution of diacylglycerylhomoserines, phospholipids and fatty acids in thirteen Moss species from southwestern Siberia. Biochem Syst Ecol 1995; 23:71-78.

34. Kato M, Sakai M, Adachi K, Ikemoto H, Sano H. Distribution of betaine lipids in marine algae. Phytochemistry 1996; 42:1341-1345.

35. Dembitsky VM, Rezanka T, Bychek IA. Seasonal variation of lipids and fatty acids from tree-growing lichens of the genus Physcia. Phytochemistry 1994; 36:601-608.

36. Dembitsky VM, Rezanka T, Bychek IA. Seasonal variability of lipids and fatty acids in the tree-growing lichen Xanthoria parietina $\mathrm{L}$. J Exp Bot 1994; 45:403-408.

37. Dembitsky VM. Lipids of Bryophytes. Prog Lipid Res 1993 32:281-356.

38. Rozentsvet OA. Comparative examination of distribution of phospholipids and a betaine lipid DGTS in tropical fern species. Biochem Syst Ecol 2004; 32:303-311.

39. Rozentsvet OA, Dembitsky VM, Saksonov SV. Occurrence of diacylglyceryltrimethylhomoserines and major phospholipids in some plants. Phytochemistry 2000; 54:401-407.

40. Lumbsch HT. Analysis of phenolic products in lichens for identification and taxonomy. Protocol Lichenol 2002; 281-295.

41. Feige GB, Lumbsch H T, Huneck S, Elix JA. Identification of lichen substances by a standardized high-performance liquid chromatographic method. J Chromatogr 1993; 646:417-427.

42. Hawksworth DL. Chemical strains of the lichen Ramalina subfarinacea. Botaniska Notiser 1968; 121:317-320.

43. Bowler PA, Smith CW. Ramalina farinacea in Hawaii. Bryologist 1976; 79:499-501.
44. Seshadri TR, Subramanian SS. Indian lichens. VIII. Lichens growing on sandal trees. Proc Indian Acad Sci 1949; 30A:15-22.

45. Hanuš LO, Temina M, Dembitsky VM. Antibacterial and antifungal activities of some phenolic metabolites isolated from lichenized ascomycete Ramalina lacera. Nat Prod Commun 2008; 3:233-236.

46. Yamamoto Y, Mizuguchi R, Yamada Y. Tissue cultures of Usnea rubescens and Ramalina yasudae and production of usnic acid in their cultures. Agricul Biol Chem 1985; 49:3347-3348.

47. Culberson CF, La Greca S, Johnson A, Culberson WL. Trivaric acid, a new tridepside in the Ramalina americana chemotype complex (lichenized Ascomycota: Ramalinaceae). Bryologist 1999; 102:595-601.

48. Pereira I, Amaro JM, Astudillo L, Padilla C, Lobos O, Santos LS Assessment of antibacterial and antifungic activity in four lichen species of Maule region in Chile. 7th European Workshop of Biotechnologists of microalgae and other phototrophic organisms. p 60, Nuthetal, Germany, 2007.

49. Huneck S, Follmann G. Lichen constituents. XX. Chemistry of Chilean lichens. 8. Components of Ramalina chilensis. Z Naturforschung 1966; 21B:90-91.

50. Walker JRL, Lintott EA. A phytochemical register of New Zealand lichens. New Zealand J Bot 1997; 35:369-384.

51. Sunil Kumar KC, Banskota AH, Manandhar MD. Chemical constituents and antibacterial activity of Ramalina subcomplanata. J Nepal Chem Soc 1995; 14:28-35

52. Honda NK, Brum RL, Marques MR, Marcelli MP, Fleig M, Vilegas W. Fungitoxic activity of compounds isolated from lichens. Southern Brazilian J Chem 1999; 7:61-66.

53. Sunil Kumar KC, Klaus M. Lichen metabolites. 2. Antiproliferative and cytotoxic activity of gyrophoric, usnic, and diffractaic acid on human keratinocyte growth. J Nat Prod 1999; 62:821-823.

54. Yamamoto Y, Miura Y, Kinoshita Y, Higuchi M, Yamada Y, Murakami A, Ohigashi H, Koshimizu K. Screening of tissue cultures and thalli of lichens and some of their active constituents for inhibition of tumor promoter-induced Epstein-Barr virus activation. Chem Pharm Bull 1995; 43:1388-1390.

55. Gomes AT, Smania A Jr, Seidel C, de Fatima Albino Smania E, Honda NK, Roese FM, Muzzi RM. Antibacterial activity of orsellinates. Brazilian J Microbiol 2003; 34:194-196.

56. Tay T, Turk AO, Yilmaz M, Turk H, Kivanc M. Evaluation of the antimicrobial activity of the acetone extract of the lichen Ramalina farinacea and its (+)-usnic acid, norstictic acid, and protocetraric acid constituents. Z Naturforschung 2004; 59C:384-388.

57. Koparal AT, Ayaz Tuylu B, Turk H. In vitro cytotoxic activities of (+)-usnic acid and (-)-usnic acid on V79, A549, and human lymphocyte cells and their non-genotoxicity on human lymphocytes. Nat Prod Res 2006; 20B:1300-1307.

58. Ingolfsdottir K. Usnic acid. Phytochemistry 2002; 61:729-736.

59. Ishihara K, Murata M, Kaneniwa M, Saito H, Komatsu W, Shinohara K. Purification of stearidonic acid (18:4(n-3)) and hexadecatetraenoic acid (16:4(n-3)) from algal fatty acid with lipase and medium pressure liquid chromatography. Biosci Biotech Biochem 2000; 64:2454-2457.

60. Alamsjah MA, Hirao S, Ishibashi F, Fujita Y. Isolation and structure determination of algicidal compounds from Ulva fasciata. Biosci Biotech Biochem 2005; 69:2186-2192.

61. Findlay JA, Patil AD. Antibacterial constituents of the diatom Navicula delognei. J Nat Prod 1984; 47:815-818.

62. Ren J, Han EJ, Chung SH. In vivo and in vitro anti-inflammatory activities of $\alpha$-linolenic acid isolated from Actinidia polygama fruits. Arch Pharm Res 2007; 30:708-714. 